\title{
Correction: Recent development of AAV-based gene therapies for inner ear disorders
}

\author{
Yiyang Lan · Yong Tao · Yunfeng Wang • Junzi Ke - Qiuxiang Yang · Xiaoyi Liu • Bing Su • Yiling Wu · Chao-Po Lin • \\ Guisheng Zhong
}

Published online: 10 August 2020

(c) The Author(s) 2020. This article is published with open access

\section{Correction to: Gene Therapy \\ https://doi.org/10.1038/s41434-020-0155-7}

Since publication of the original article, the authors noticed some errors in the reference list, which were missed at proofing. References 57, 58, 60, 61, 62, and 64 were formatted incorrectly with first names written in full with last name initials, rather than last names written in full with first name initials. Reference 63 cited an incorrect paper and has been replaced with the following paper: "Nist-Lund CA, Pan B, Patterson A, Asai Y, Chen T, Zhou W, et al. Improved TMC1 gene therapy restores hearing and balance in mice with genetic inner ear disorders. Nat Commun. 2019;10:236". Furthermore, references 43 and 65 were duplicates of previous references in the list and have been deleted.

After some consideration the authors realised that the references cited in Table 2 for some genes were not the most relevant and so have offered replacements for the following specified genes:

(1) Slc26a5 (Refs. 68 and 69) was replaced with "Zheng J, Shen W, He DZ, Long KB, Madison LD, Dallos P. Prestin is the motor protein of cochlear outer hair cells. Nature. 2000;405:149-55."

(2) Myo7a (Ref. 84) was replaced with "Li S, Mecca A, Kim J, Caprara GA, Wagner EL, Du T-T, et al. Myosin-VIIa is expressed in multiple isoforms and essential for tensioning the hair cell mechanotransduction complex. Nat Commun. 2020;11:2066."

(3) Lgr5 (Ref. 71) was replaced with "BerminghamMcDonogh O, Oesterle EC, Stone JS, Hume CR,
Huynh HM, Hayashi T. Expression of Prox1 during mouse cochlear development. J Comp Neurol. 2006;496:172-86."

(4) Tuj1 (Ref. 79) was replaced with "Huang X, Liu J, Wu W, Hu P, Wang Q. Taurine enhances mouse cochlear neural stem cell transplantation via the cochlear lateral wall for replacement of degenerated spiral ganglion neurons via sonic hedgehog signaling pathway. Cell Tissue Res. 2019;378:49-57."

(5) Cacna1h (Ref. 95) was replaced with "Xie D, Hu P, Xiao ZA, Wu W, Chen Y, Xia K. Subunits of voltage-gated calcium channels in murine spiral ganglion cells. Acta Oto-laryngol. 2007;127:8-12."

(6) GFAP (Ref. 74) GFAP does not involve Ref.74 and so it was removed.

These changes have been made in both the HTML and PDF versions of the paper.

Open Access This article is licensed under a Creative Commons Attribution 4.0 International License, which permits use, sharing, adaptation, distribution and reproduction in any medium or format, as long as you give appropriate credit to the original author(s) and the source, provide a link to the Creative Commons license, and indicate if changes were made. The images or other third party material in this article are included in the article's Creative Commons license, unless indicated otherwise in a credit line to the material. If material is not included in the article's Creative Commons license and your intended use is not permitted by statutory regulation or exceeds the permitted use, you will need to obtain permission directly from the copyright holder. To view a copy of this license, visit http://creativecommons. org/licenses/by/4.0/. 